\title{
Cannabis Smoking and Academic Achievement in Colombian High-School Students
}

\author{
Yegson Pérez-Martínez ${ }^{1}$, Guillermo Augusto Ceballos-Ospino ${ }^{2}$ and Adalberto Campo-Arias ${ }^{3}$ \\ ${ }^{1}$ Psychologist, Universidad del Magdalena, Santa Marta, Colombia. Email: \\ yegsonperezm@unimagdalena.edu.co. https://orcid.org/0000-0003-2724-119X \\ ${ }^{2}$ Psychologist, Occasional professor, Universidad del Magdalena, Santa Marta, Colombia. Email: \\ gceballos@unimagdalena.edu.co. https://orcid.org/0000-0002-1568-7058 \\ ${ }^{3} \mathrm{MD}$, MSc, Associate professor, Universidad del Magdalena, Santa Marta, Colombia. Email: \\ acampoa@unimagdalena.edu.co. https://orcid.org/0000-0003-2201-7404
}

\section{Author note}

Correspondence to Adalberto Campo-Arias, Programa de Medicina, Facultad Ciencias de la Salud, Universidad del Magdalena, Carrera 32 No 22-08, Santa Marta, Colombia (código postal 470004). Teléfono: 575 438100, extensión 1338. The Research Vice-rectory of the Universidad del Magdalena financed this research through Resolution 0347 of 2018 in the name of Adalberto Campo-Arias (Call Fonciencias 2017). The authors have no conflicts of interest to declare.

Contributors: Yegson Pérez-Martínez contributed to the study conception and data interpretation and statistical analysis, drafted the article, and revised and approved the final version. G. A. Ceballos-Ospino and A. Campo-Arias contributed to the study design and conception, data interpretation statistical analysis, and revised the intellectual content and approved the final version.

Data availability statement: The data supporting this study's findings are available from the corresponding author upon reasonable request.

\begin{abstract}
A cross-sectional study was designed with high-school students. The study's objective was to establish the relationship between cannabis smoking and academic achievement, adjusted for clinically important depressive symptoms and family dysfunction. The authors quantified lifetime cannabis smoking, perception of academic achievement, clinically important depressive symptoms, and family dysfunction. It was computed crude association between cannabis smoking and academic achievement and adjusted by clinically important depressive symptoms and family dysfunction. A total of 1,462 students between 13 and 17 years participated in the research; $11.63 \%$ reported lifetime cannabis smoking; $30.78 \%$, poor-fair academic achievement; $7.05 \%$, clinically important depressive symptoms; and $76.06 \%$, family dysfunction. The lifetime cannabis smoking was significantly associated with poor-fair academic achievement after adjusting for clinically important depressive symptoms and family dysfunction $(O R=1.61$, $95 \%$ CI $1.16-2.24)$. In conclusion, lifetime cannabis smoking is related to poor-fair academic achievement among high-school students in Santa Marta, Colombia.

Keywords: Cannabis smoking; academic achievement; students; cross-sectional studies.
\end{abstract}




\section{Introduction}

In 2016, cannabis smoking increased worldwide, and it was the most consumed drug; around 192 million people used it at least once during that year (United Nations Office on Drugs and Crime, UNODC, 2018).

Cannabis is the substance of choice for young people due to easy access and is mistakenly considered a low health risk. Cannabis smoking usually begins in adolescence and is often the gateway to the use of other illegal substances (UNODC, 2018).

In Latin America and the Caribbean, the frequency of cannabis smoking in secondary school students follows the world trend in countries such as Argentina, Barbuda, Chile, and the Dominican Republic, prevalences close to $20 \%$ are registered. However, there are essential discrepancies in the frequency given that in countries such as Colombia and Ecuador, a prevalence of less than 10\% was documented (Inter-American Drug Abuse Control Commission, 2019).

\section{Cannabis smoking}

Cannabis smoking in adolescents is related to different risk factors: individual, peer, family, community, and social (Alfonso et al., 2009). At the individual level, cannabis smoking is associated with adjustments typical of the normative period of adolescence, among others, the need to consolidate or reaffirm an identity (Quejía et al., 2007), curiosity about new experiences, and misinformation (Pérez et al., 2012). It is hypothesized that adolescents use cannabis to seek approval and demonstrate competence (Maturana, 2011).

Among the family factors, the poor communication between father and children, poor parenting styles, parental absenteeism, and a history of substance use in the family group stand out. On the other hand, in the group of community factors, the availability of time, access to the substance in the sector, and the advertising that reaffirms the need to try new things can be pointed out (Carabaca et al., 2015).

\section{Academic achievement}

On the other hand, academic achievement cannot be reduced to a simple understanding of students' attitudes and aptitudes (Lamas, 2015). Academic achievement also implies fulfilling goals, achievements, and objectives in the courses (Caballero \& Palacio, 2007) and the knowledge shown in the subjects studied in qualitative and quantitative measurements (Velázquez \& Soriano, 2006).

Different factors influence academic achievement, some personal and others associated with the family and school context (Moreno \& Chauta, 2012). Personal factors characterize the student as a learner (González, 2003). The multiple academic objectives and goals that intrinsically motivate the student in academic settings should be considered (Chiecher, 2017).

On the other side, the contextual factors refer to the family, social, economic status, and the school environment where the student develops (Hernández \& Gonzales, 2011; Velázquez \& Soriano, 2006). Likewise, contextual factors may include the relevance of the perception of performance by parents. This aspect is crucial because it can become a stressor that mediates the student's psychological well-being and self-concept (Alcalay et al., 2003). Consequently, it can 
be affirmed that parents can directly or indirectly influence academic achievement (Lozano et al., 2012).

\section{Association between cannabis smoking and academic achievement}

Cannabis smoking can affect academic achievement; for example, Hayatbakhsh et al. (2008), in a sample of 3478 Australian students, found that frequent cannabis smoking increased almost twice the risk of low academic achievement. Cox et al. (2007) found in 1488 high school students from the United States that cannabis smoking was two-fold associated with low academic achievement. Finally, Guerrero-Martelo et al. (2015), in 156 Colombian students, found that cannabis smoking increased ten times the risk of low academic achievement.

\section{Confounding variables in the relationship between cannabis smoking and academic achievement: Depressive symptoms and family dysfunction}

\section{Depressive symptoms, cannabis smoking, and academic achievement}

It should be considered that the association between cannabis smoking and academic achievement can be modified by the presence of other variables such as depressive symptoms and family functioning (Campo-Arias et al., 2005; Cogollo \& Campo-Arias, 2007; GómezBustamante et al., 2013; Mejía et al., 2011; Zarrouq et al., 2016).

First, it should be considered that cannabis smoking can be associated with depressive symptoms and be a confusing variable in the association between cannabis smoking and academic achievement since depressive symptoms can independently affect academic achievement. Rojas et al. (2012) found that in a sample of 2597 Chilean students that cannabis smoking increased two times the risk of depression.

In the same way, it is observed that depressive symptoms can negatively affect academic achievement. In Colombia, Campo-Arias et al. (2005), in a sample of 560 students from Bucaramanga, observed that depressive symptoms with clinical importance were related at least two-fold to low academic achievement. Mejía et al. (2011), in 385 students from Santa Marta, found that depressive symptoms showed three times the risk of low or fair academic achievement. However, Cogollo \& Campo-Arias et al. (2007), in a sample of 512 students from a public school in Cartagena, documented that depressive symptoms did not maintain a significant relationship with academic achievement.

Family function, cannabis smoking, and academic achievement

Another variable that can qualify the relationship between cannabis smoking and academic achievement is family functioning. Zarrouq et al. (2016), in 3020 students from Morocco, between 11 and 23 years old, found that feeling insecure with the family, one of the components measured for the family function, was significantly associated two-fold with substance use psychoactive.

Likewise, a statistically significant association between family function and academic achievement is observed. Gómez-Bustamante et al. (2013), in 1730 students from Cartagena, Colombia, between 13 and 17 years, found that family dysfunction was almost two times related to low academic achievement. 
The studies' limitations in the association between cannabis smoking, academic achievement, depressive symptoms, and family dysfunction are common. The studies that analyzed the association between cannabis smoking and academic achievement did not adjust for the relationship with confounding variables, such as depressive symptoms and family function (Cox et al., 2007; Ehrenreich, 2014; Guerrero-Martelo et al., 2015; Navalon-Mira \& RuizCallado, 2017). In the present research, the association between cannabis smoking and academic achievement was studied, adjusted for depressive symptoms and family function since these variables can act as confounding variables or interact with academic achievement (De Irala et al., 2001).

\section{Theoretical bases of the association}

The use of substances, such as cannabis, is a learned behavior that can be modified and extinguished (García et al., 2015). A behavior from which pleasure and approval are obtained tends to repeat itself; it can be configured as a habitual behavior (Reynolds, 1973). On the other hand, if the behavior does not obtain satisfying results, it is less likely to repeat and, consequently, the probability of becoming a habit is reduced (García et al., 2015).

The association between cannabis smoking and academic achievement can be explained by neuropsychology due to the neurological damage induced by cannabis (Portellano, 2000). This theory explains that cannabis smoking directly affects the central nervous system's functioning, mainly on synaptic function, related to neurotransmitters (National Institute on Drug Abuse, 2020, Rubino et al., 2009). Delta-9-tetrahydrocannabinol and endogenous cannabinoids, such as anandamide, are related to repeated consumption patterns that can inhibit the production or block the reception of neurotransmitters in the synaptic cleft (National Institute on Drug Abuse, 2020). These changes directly affect higher mental functions, such as information processing, reflective thinking, memory, motor activity, and visual perception (Macleod et al., 2004; National Institute on Drug Abuse, 2020; Robbins et al., 2008). The integrity of functions is necessary for the school setting to achieve excellent academic achievement (Portellano, 2000).

Similarly, the theory of cognitive distortions can convincingly explain the relationship between depressive symptoms and academic achievement (Levine et al., 2019). Negative emotional states such as depression generate errors in information processing; such distortions can manifest as disruptive behaviors or low academic achievement (Beck, 1979). In this way, people with depressive symptoms present what is known as the negative cognitive triad, which causes the individual to have a negative view of himself, the world, and the future, which can be reflected in little interest in achieving goals such as an excellent academic achievement (Levine et al., 2019). The cognitive distortions associated with depressive symptoms directly affect the individual (Hoyos et al., 2007), such as labeling, polarized thinking, overgeneralization, guilt, catastrophizing, and emotional reasoning (Levine et al., 2019). These alterations limit the learning process, its motivation is reduced, and it interferes with intellectual activity, a consequence of which is directly reflected in academic achievement (Barquín, 2013; Ortega et al., 2014).

On the other hand, Bertalanffy's general system theory explains the relationship between family function and academic achievement (1976). This theory explains the organization of various phenomena in which different variables or actors participate (Espinal et al., 2006). Human development is framed in different interaction scenarios with the environment, ecological theory (Bronfenbrenner, 1986). This postulate maintains that the family is the system that 
broadly defines and configures the development of the person, in which it is affirmed as systems, microsystems, areas close to the individual (family, school, peer group, the neighborhood), mesosystems (interaction of two or more microsystems), macrosystems (culture, and ideologies), directly influence or affect development in the individual (Bronfenbrenner, 1986).

Human development is framed and congregates from the influence of different family systems, schools, peers, and cultures, all related to each other (Bronfenbrenner, 1986). Likewise, if any of these systems are dysfunctional, they can negatively impact each individual's development that makes it up (Bronfenbrenner, 1986). Substance use, family dysfunction, and depressive symptoms, only in conjunction or interaction, affect academic performance and can be indicators of problems in the systems in which students operate due to their dynamic structure (Bertalanffy, 1976).

Depressive symptoms are associated with cognitive distortions (Beck, 1979; Levine et al., 2019) that can minimize the risk of cannabis smoking (Bronfenbrenner, 1986). Likewise, it should be remembered that depressive episodes can manifest as difficulty concentrating on academic work (American Psychiatric Association 2013; World Health Organization, 1992) and decreased self-efficacy (Moyeda et al., 2013). Also, it is necessary to remember that cannabis smoking can be a form of self-medication to face or escape the stress associated with family function or the discomfort typical of depressive symptoms (Morales-Manrique et al., 2011; Parreño et al., 2011). Stress and cannabis smoking can have a negative brain effect in the short and long term on higher mental functions that can explain the low academic achievement (Portellano, 2000; Robbins et al., 2008).

\section{Practical implications}

Thanks to the knowledge of the variables that influence the acquisition of behavior and the fundamental role of reinforcers (Ormrod et al., 2005). Strategies can be established to modify behaviors that generate a risk to the health of individuals, such as consumption; if the reduction of reinforcers that maintain these behaviors is changed and if they enhance those protective factors, more acceptable social behaviors can be achieved (García et al., 2015).

The present study's findings may contribute to the recognition that low academic achievement is not only due to factors intrinsic to students, but different contextual elements can influence, directly or indirectly, and condition academic achievement (González, 2017). This knowledge allows us to justify the creation of programs for teachers. Educators have the role of guiding and change agents to decrease cannabis smoking (Acevedo et al., 2016; Bisquerra, 2006; Carreño et al., 2007; Gómez-Restrepo et al., 2016). Furthermore, the findings suggest working in an interdisciplinary way to address the risk factors (Bisquerra, 2006; Carreño et al., 2007) and identify possible cases of significant cannabis smoking or depressive symptoms. These strategies can favor academic achievement and reduce depressive symptoms with the family system (Acevedo et al., 2016; Carreño et al., 2007; Martín \& Megret, 2013).

Based on the fact that the family is the social institution that integrates the factors, it is previously noted for the integral formation of children and adolescents (Martín, \& Megret, 2013). The family plays a fundamental role from childhood in the foundation of the personality bases. Most of the habits and customs maintained throughout life are initiated and consolidated (Medina \& Ferriani, 2010; Montañés et al., 2008). Proper family functioning may be necessary to reduce initiation and maintenance in cannabis smoking and, at the same time, to achieve the best achievements in school (Santander et al., 2008). 
This study's objective was to estimate the association between cannabis smoking and academic achievement, adjusted by depressive symptoms and family function, in high school students from Santa Marta, Colombia.

\section{Method}

\section{Design and ethical considerations}

This project was reviewed and approved by a research ethics committee of a public higher education institution. It was designed as a cross-sectional study. Research Ethical Board of the Universidad del Magdalena, Santa Marta, Colombia approved the project in ordinary session on July 12, 2018. Parents or guardians must sign an informed consent, and the students give their consent to participate in the research.

\section{Population and sample}

The District Secretary of Education of Santa Marta's registry in 2017 reported 10,810 students enrolled in secondary education, that is, tenth and eleventh grade in public and private educational institutions. A probabilistic sampling was followed in several stages based on clusters. The size of each cluster was an estimated 25 students. This sample size allows working with prevalence between $3 \%(+/-1)$ and $50(+/-5)$, with a confidence level of $95 \%$. Additionally, a $20 \%$ replacement was calculated to cover possible losses due to different eventualities, such as denying educational institutions' authority, not having the parents' informed consent, or denying assent by the students. Thus, a sample of 1,948 students was projected. This sample size would also allow associations to be explored and adjusted with relatively narrow 95\% confidence intervals. Students between the ages of 13 and 17 with the skills to fill out the research booklet were included.

\section{Instruments}

\section{Cannabis smoking}

The cannabis smoking in the life course was quantified with one item taken from the epidemiological surveillance of risk behaviors in middle-school students in the United States, YOUTH: Have you ever used marijuana? The item presents a dichotomous response option (Kann, 2016). This questionnaire has acceptable reproducibility in-school adolescents (Brenner et al., 2013).

\section{Academic achievement}

During the last month, the perception of academic achievement was evaluated with an item taken from the VESPA questionnaire. This item presents four response options: excellent, good, fair, and poor (Torres et al., 1994). For the present analysis, the responses were dichotomized into excellent/good and poor/fair. 


\section{Depressive symptoms}

Depressive symptoms were quantified with the World Health Organization General Well-being Index (IBG-WHO-5). The IBG-WHO-5 has five items that address the perception of general well-being: the absence of depressive symptoms during the last fifteen days: good mood, tranquility, feeling energetic, quality of sleep, and interest in daily life activities. Each item has four response options: never, sometimes, many times, and always. Each response is scored from zero to three. Consequently, the total scores are between zero and fifteen; the lower the score, the more depressive symptoms (World Health Organization: Regional Office for Europe, 1998). In the present study, scores were dichotomized into depressive symptoms without and with clinical significance, and scores of 8 or less were categorized as depressive symptoms with clinical significance. The WBI-WHO-5 showed excellent internal consistency and reproducibility in adolescents from a city in the Colombian Caribbean (Campo-Arias et al., 2015). The WBIWHO-5 presented a Cronbach's alpha of 0.82 in the current sample.

\section{Family functioning}

The family function was quantified with the family APGAR. This questionnaire consists of five items that address the family group's adaptability, cooperation, development, affectivity, and resolution capacity. Each item gives five response options: never, seldom, sometimes, almost always, and always. The options are scored between zero and four; therefore, the total scores range between zero and twenty (Smilkstein, 1978). In the present study, the scores were dichotomized, and those of fifteen or less were categorized as family dysfunction. The family APGAR presented high internal consistency in adolescents from Cartagena, Colombia (Forero et al., 2006). In the present study, the family APGAR showed a Cronbach's alpha of 0.81 .

\section{Procedure}

The information collection process was carried out between September 1 and October 31, 2018. The students completed the questionnaire as a group on an ordinary day in the classroom. In the classroom, the research assistants' team explained the research's objectives, the importance of omitting the name to fill out the item booklet anonymously, and the general rules for responding. In the same way, the group of research assistants offered to clarify doubts without inducing responses.

\section{Analysis of data}

For the analysis, cannabis smoking was the independent variable, academic achievement was the dependent variable, and family function and depressive symptoms as confounding variables. First, crude odds ratios $(O R)$ with a $95 \%$ confidence interval $(95 \% C I)$ were estimated; after, adjusted $O R$ for the family function and depressive symptoms was computed. The analysis was performed using the IBM-SPSS version 22 program. 


\section{Results}

A total of 1,462 students participated in the research, the ages were between 13 and $17(M=$ $15.98, S D=0.83$ ). The sociodemographic description of the student sample is presented as dichotomous variables in Table 1.

A total of 170 students $(11.63 \%)$ reported cannabis smoking; 450 students $(30.78 \%)$, poorfair academic achievement; 103 students (7.05\%), depressive symptoms; and 1,112 students (76.06\%), family dysfunction.

Table 1. Demographic characteristics of the high-school students.

\begin{tabular}{lrr}
\hline Variable & $\mathrm{n}$ & $\%$ \\
\hline Age (years) & & \\
$13-15$ & 425 & 29.1 \\
$16-17$ & 1037 & 70.9 \\
\hline Gender & & \\
Female & 882 & 60.3 \\
Male & 580 & 39.7 \\
\hline Grade & & \\
Tenth & 809 & 55.3 \\
Eleventh & 653 & 44.7 \\
\hline Socioeconomic status & & \\
Low & 725 & 49.6 \\
Middle & 508 & 34.7 \\
High & 39 & 2.6 \\
No answer & 190 & 13.0 \\
\hline
\end{tabular}

Cannabis smoking was significantly associated with poor-fair academic achievement $(O R=1.73$, $95 \%$ CI 1.25 - 2.40). Even after adjusting for depressive symptoms and family dysfunction (OR $=1.61,95 \%$ CI $1.16-2.24)$.

\section{Discussion}

The present study shows the association between cannabis smoking and academic achievement; after controlling for depressive symptoms and family dysfunction, a significant association was maintained with the variables adjusted for poor-fair academic achievement.

This finding is similar to other cross-sectional studies that found a statistically significant association between cannabis smoking and low academic achievement (Cox et al., 2007; Guerrero et al., 2015; Hayatbakhsh et al., 2008). Some longitudinal studies showed that cannabis smoking increased academic dropout risk (Fergusson et al., 2003; Lynskey et al., 2003; Verwij et al., 2013); academic dropout is generally associated with a poor academic achievement (Duque et al., 2013). Likewise, it was observed that the age of onset of cannabis smoking was associated with low academic achievement and reduced the chance of graduating (Macleod et al., 2004). Adolescents who started cannabis smoking earlier showed lower academic achievement than those who started cannabis smoking at an older age (Horwood et al., 2010; Melchior et al., 2017). However, in a study with 92 participants with a history of cannabis smoking, it was 
observed that cannabis smoking was not associated with a missing school or repeating the last year (Hamdulay \& Mash, 2011). Similarly, no statistically significant association was found between cannabis smoking and academic achievement after controlling cigarette smoking and alcohol consumption (Meier et al., 2015).

Given the study's cross-sectional design, it might be thought that low academic achievement could increase cannabis smoking. In agreement with this hypothesis, Brook et al. (2008) and Hayatbakhsh et al. (2008) observed, in two longitudinal studies, that habitual cannabis smoking increased the risk of low academic achievement. However, in a cohort study, Fergusson et al. (2003) did not observe that low academic achievement increased the risk of cannabis smoking. Likewise, Grant et al. (2012) did not find a difference in academic achievement at 16 years of age and the age of onset of cannabis smoking in pairs of twins.

Early and prolonged exposure to cannabis smoking can cause significant alterations in higher cognitive functions due to functional and structural alterations at the brain level (Robbins et al., 2008; Rubino et al., 2009). Depending on the use pattern, cannabis negatively affects attention, memory, and learning up to weeks after the acute effects associated with the substance (Schweinsburg et al., 2008; Volkow et al., 2016). However, in the present study, lifetime cannabis smoking was only quantified without investigating the age of onset and frequency of use. It is possible that in adolescents, cannabis smoking can be a form of self-medication to face negative emotional states, such as depressive symptoms and those associated with family dysfunction, and thus affect academic achievement (Gómez-Bustamante et al., 2013). Family dysfunction and depressive symptoms can also negatively affect academic achievement (CampoArias et al., 2005; Cogollo \& Campo-Arias, 2007; Gómez-Bustamante et al., 2013; Mejía et al., 2011; Zarrouq et al., 2016). Hence, adjusting simultaneously for these confounding variables is necessary (De Irala et al., 2001).

Depressive symptoms are associated with errors in information processing and cognitive distortions such as labeling, polarized thinking, overgeneralization, guilt, catastrophization, and emotional reasoning (Beck, 1979; Levine et al., 2019). These changes reduce self-efficacy, motivation and hinder learning; consequently, they are reflected in reduced academic achievement (Barquín, 2013; Ortega et al., 2014).

Likewise, family dysfunction can be considered an essential stressor in the student's life that disturbs emotional well-being and can deteriorate academic achievement (GómezBustamante et al., 2013). It is necessary to control family function in Colombian studies that investigate variables associated with academic performance. Family dysfunction is highly prevalent in Colombian families with adolescent children (Cogollo \& Campo-Arias, 2007; Gómez-Bustamante et al., 2013).

Academic achievement results from intrinsic and extrinsic variables (Chiecher, 2017; Hernández \& Gonzales, 2011; Velázquez \& Soriano, 2006). The design of the present study suggests that cannabis smoking can impair academic achievement; but, in turn, depressive symptoms and family dysfunction can increase the risk of both cannabis smoking and deteriorate academic achievement (Campo-Arias et al. 2005; Cogollo \& Campo-Arias, 2007; Cox et al. 2007; Gómez-Bustamante et al., 2013; Hayatbakhsh et al. 2008; Mejía et al., 2011; Zarrouq et al., 2016). Consequently, low academic achievement cases must be studied comprehensively and consider many variables (Cogollo \& Campo-Arias, 2007; Gómez-Bustamante et al., 2013). 


\section{Strengths and limitations}

Thus, this research's critical contribution was to analyze the relationship between cannabis smoking and academic achievement after adjusting depressive symptoms and family function, previously not considered confounding variables in the association. However, this study has limitations; it is impossible to establish causal relationships between the variables because these are simultaneously measured (Álvarez \& Delgado, 2015; Rodríguez \& Mendivelso, 2018). Besides, cannabis smoking frequency was not established. The severity of consumption is directly related to a negative impact at the cognitive level (National Institute on Drug Abuse, 2020; Robins et al., 2008) and, consequently, on academic performance (National Institute on Drug Abuse, 2020; Portellano, 2000).

\section{Conclusions}

It is concluded that cannabis smoking is significantly associated with poor-fair academic achievement after adjusting for depressive symptoms and family dysfunction in high school students from Santa Marta, Colombia. Further research and consideration of other confounding variables are needed.

\section{References}

Acevedo S. M., Camargo C. L., \& Fajardo L. E. (2016). Factores protectores familiares para la prevención del uso de sustancias psicoactivas (SPA) en estudiantes de quinto de primaria de la Institución Educativa San Luis Gonzaga del corregimiento de Chicoral, El Espinal (Tolima) [Family protective factors for the prevention of the use of psychoactive substances in fifth-grade students of educational institution San Luis Gonzaga the village Chicoral (El Espinal, Tolima). Salud Uninorte, 32(3), 461-471.

Alcalay, L., Flores, A., Milicic, N., Portales, J., \& Torretti, A. (2003). Familia y escuelas ¿Una alianza posible? Una mirada desde la perspectiva de los estudiantes [Family and school. A possible alliance? A look from the perspective of studies]. Psykhe, 12(2), 101-110.

Alfonso, J. P., Huedo-Medina, T. B., \& Espada, J. P. (2009). Factores de riesgo predictores del patrón de consumo de drogas durante la adolescencia [Risk factors predictors of the pattern of substance use during the adolescence]. Anales de Psicología, 25(2), 330-338.

Álvarez-Hernández, G., \& Delgado-de la Mora, J. (2015). Diseño de estudios epidemiológicos. I. El estudio transversal: tomando una fotografía de la salud y la enfermedad [Epidemiologic research design. Cross-sectional survey]. Boletín Clínico Hospital Infantil del Estado de Sonora, 32(1), 26-34.

American Psychiatric Association. (2013). Desk Reference to the diagnostic criteria from DSM5. Washington, DC: American Psychiatric Publishing.

Barquín, C. S., García, A. R., \& Ruggero, C. (2013). Depresión, ansiedad y rendimiento académico en estudiantes universitarios [Depression, anxiety and academic performance in college students]. Revista Intercontinental de Psicología y Educación, 15(1), 47-60.

Beck, A. T. (1979). Cognitive therapy of depression. New York: Guilford Press.

Bertalanffy, L. (1976). Teoría general de los sistemas [General theory of the systems]. México: Editorial Fondo de Cultura Económica. 
Bisquerra, R. A., (2006). Orientación psicopedagógica y educación emocional [Psychoeducational guidance and counseling and emotional education]. Estudios sobre Educación, 11, 9-25.

Brener, N., Eaton, D. K., Flint, K., Hawkins J., Kann, L., Kinchen S., \& Shanklin S. (2013). Methodology of the Youth Risk Behavior Surveillance System. Morbidity and Mortality Weekly Report: Recommendations and Reports, 62(1), 1-20. https://www.jstor.org/stable/24832543

Bronfenbrenner, U. (1986). Ecology of the family as a context for human development: research perspectives. Developmental Psychology, 22(6), 723-742. https://doi.org/10.1037/00121649.22.6.723

Brook, J. S., Stimmel, M. A., Zhang, C., \& Brook, D. W. (2008). The association between earlier marijuana use and subsequent academic achievement and health problems: A longitudinal study. The American Journal on Addictions, 17(2), 155-160. https://doi.org/10.1080/10550490701860930

Caballero, C. C., \& Palacio, S. (2007). Relación del burnout y el rendimiento académico con la satisfacción frente a los estudios en estudiantes universitarios [Relationship between burnout and academic performance with satisfaction with studies in university students]. Avances en Psicología Latinoamericana, 25(2), 98-111.

Campo-Arias, A., González, S. J., Sánchez, Z., Rodríguez, D. C., Dallos, C. M., \& DíazMartínez, L. A. (2005). Percepción de rendimiento académico y síntomas depresivos en estudiantes de Bucaramanga, Colombia [Perception of academic performance and depressive symptoms in high school students from Bucaramanga, Colombia]. Archivos de Pediatría del Uruguay, 76(1), 21-26.

Campo-Arias, A., Miranda-Tapia, G., Cogollo, Z., \& Herazo, E. (2015). Reproducibilidad del Índice de Bienestar General (WHO-5 WBI) en estudiantes adolescentes [Reproducibility of the Weil-Being Index (WHO-5 WBI) among adolescent students]. Salud Uninorte, 31(1), $18-24$.

Caravaca, J. A., Noh, S., Hamilton, H., Brands, B., Gastaldo, D., \& Miotto, M. G. (2015). Sociocultural factors e drug consumption among Costarrican university students. Texto \& Contexto-Enfermagem, 24(Spec), $\quad$ 145-153. https://doi.org/10.1590/010407072015001170014

Carreño, Á. B., Cruz, M., \& Tenorio, M. S. (2007). What does a counselor do?: Roles and functions of the counselor in secondary education. En-clave Pedagógica, 9(1), 111-131.

Chiecher, A. C. (2017). Metas y contextos de aprendizaje. Un estudio con alumnos del primer año de carreras de ingeniería [Goals and contexts of learning. A study with first-year engineering students]. Innovación Educativa, 17(74), 61-80.

Cogollo, Z., \& Campo-Arias, A. (2007). Asociación entre síntomas depresivos clínicamente importantes y rendimiento académico en estudiantes de Cartagena, Colombia [Association between clinically important depressive symptoms and academic achievement among students in Cartagena, Colombia]. Revista Ciencias de la Salud, 5(1), 33-39.

Cogollo-Milanés, Z., Arrieta-Vergara, K. M., Blanco-Bayuelo, S., Ramos-Martínez, L., Zapata, K., \& Rodríguez-Berrio, Y. (2011). Public university students' psychosocial factors associated with legal and illegal substance consumption. Revista de Salud Pública, 13(4), 470-479.

Duque, L. C., Duque, J. C., \& Suriñach, J. (2013). Learning outcomes and dropout intentions: an analytical model for Spanish universities. Educational Studies, 39(3), 261-284. 
Inter-American Drug Abuse Control Commission. (2019). Report on Drug Use in the Americas 2019. Washington, D.C.

Cox, R. G., Zhang, L., Johnson, W. D., \& Bender, D. R. (2007). Academic performance and substance use: findings from a state survey of public high school students. Journal of School Health, 77(3), 109-115. https://doi.org/10.1111/j.1746-1561.2007.00179.x

De Irala, J., Martínez-González, M., \& Grima, F. G. (2001). ¿Qué es una variable de confusión? [What is a confounding variable?] Medicina Clínica, 117(10), 377-385.

Ehrenreich, H., Nahapetyan, L., Orpinas, P., \& Song, X. (2014). Marijuana use from middle to high school: co-occurring problem behaviors, teacher-rated academic skills and sixth-grade predictors. Journal of Youth and Adolescence, 44(10), 1929-1940. https://doi.org/10.1007/s10964-014-0216-6

Espinal, I., Gimeno, A., \& González, F. (2006). El enfoque de sistemas en los estudios de familia [The systems approach in family studies]. Revista Internacional de Sistemas, 14(4), 21-34.

Fergusson, D. M., Horwood, L. J., \& Beautrais, A. L. (2003). Cannabis and educational achievement. Addiction, 98(12), 1681-1692. https://doi.org/10.1111/j.13600443.2003.00573.x

Forero, L., Avendaño, M., Duarte, Z., \& Campo-Arias, A. (2006). Consistencia interna y análisis de factores de la escala APGAR para evaluar el funcionamiento familiar en estudiantes de básica secundaria [Internal consistency and factorial analysis of family functioning APGAR scale in middle school Students]. Revista Colombiana de Psiquiatría 35(1), 23 29.

García, F., Fonseca, G., \& Concha, L. (2015). Aprendizaje y rendimiento académico en la educación superior: un estudio comparativo [Learning and academic achievement in higher education: a comparative study]. Actualidades Investigativas en Educación, 15(3), 404429.

Gómez-Bustamante, E. M., Castillo-Ávila, I., \& Cogollo, Z. (2013). Predictores de disfunción familiar en estudiantes adolescentes [Predictors of family dysfunction among adolescent students]. Revista Colombiana de Psiquiatría, 42(1), 72-80. https://doi.org/10.1016/S00347450(14)60088-3

Gómez-Restrepo, C., Padilla, M. A., \& Rincón C. J. (2016). Estudio transversal de la deserción escolar en adolescentes: Encuesta Nacional de Salud Mental Colombia 2015 [A crosssectional study of school dropout in adolescents: National Mental Health Survey Colombia 2015]. Revista Colombiana de Psiquiatría, 45(S1), 105-112. https://doi.org/10.1016/j.rcp.2016.09.003.

González, E. G. C. (2017). Factores que afectan el desempeño académico de los estudiantes de la Universidad Politécnica del Valle de Toluca [Factors affecting the academic performance of students of the Universidad Politécnica del Valle de Toluca]. Revista Latinoamericana de Estudios Educativos (México), 47(1), 91-108.

González-Pienda, J. A. (2003). School performance. An analysis of the variables that condition it. Revista Galego-Portuguesa de Psicoloxia e Educación, 8(7), 1138-1663.

Grant, J. D., Scherrer, J. F., Lynskey, M. T., Agrawal, A., Duncan, A. E., Haber, J. R., Heath, A.C., \& Bucholz, K. K. (2012). Associations of alcohol, nicotine, cannabis, and drug use/dependence with educational attainment: Evidence from cotwin $\square$ control analyses. Alcoholism: Clinical and Experimental Research,36(8), 1412-1420. https://doi.org/10.1111/j.1530-0277.2012.01752.x 
Guerrero-Martelo, M., Galván, G., Pinedo-López, J., Vásquez-De la Hoz, F., Torres-Hoyos, F., \& Torres-Oviedo, J. (2015). Prevalencia de por vida de consumo de cannabis y rendimiento académico en adolescentes [Lifetime prevalence of cannabis use and academic performance in adolescents]. Salud Uninorte, 31(3), 467-678.

Hamdulay, A. K., \& Mash, R. (2011). The prevalence of substance use and its associations amongst students attending high school in Mitchells Plain, Cape Town. South African Family Practice, 53(1), 83-90. https://doi.org/10.1080/20786204.2011.10874065

Hayatbakhsh, M. R., O'Callaghan, M. J., Jamrozik, K., Najman, J. M., Mamun, A. A., Alati, R., \& Bor, W. (2008). The association between school performance at 14 years and young adults' use of cannabis: An Australian birth cohort study. Journal of Drug Issues, 38(2), 401-418. https://doi.org/10.1177\%2F002204260803800202

Hernández, E., \& González, M. J. (2011). Un modelo para una ecuación estructural mediante el cual evaluar las relaciones entre el estado cultural y económico de los estudiantes y su rendimiento educativo [A model for a structural equation by which to evaluate the relationships between students' cultural and economic status and their educational achievement]. Revista Electrónica de Investigación Educativa, 13(2), 188-203.

Horwood, L. J., Fergusson, D. M., Hayatbakhsh, M. R., Najman, J. M., Coffey, C., Patton, G. C., Silins, E., \& Hutchinson, D. M. (2010). Cannabis use and educational achievement: findings from three Australasian cohort studies. Drug and Alcohol Dependence, 110(3), 247-253. https://doi.org/10.1016/j.drugalcdep.2010.03.008

Hoyos, M. L., Arredondo, N., \& Echavarría, J. A. Z. (2007). Distorsiones cognitivas en personas con dependencia emocional [Cognitive distortions in people with emotional dependence]. Informes Psicológicos, 9(9), 55-69.

Kann, L. (2016). Youth risk behavior surveillance-United States (2015). Surveillance Summaries, 65(6), 1-174. https://www.jstor.org/stable/24805802

Lamas, H. A. (2015). School performance. Journal of Educational Psychology, 3(1), 351-385.

Levine, S. L., Green-Demers, I., Werner, K. M., \& Milyavskaya, M. (2019). Perfectionism in adolescents: Self-critical perfectionism as a predictor of depressive symptoms across the school year. Journal of Social and Clinical Psychology,38(1), 70-86. https://doi.org/10.1521/jscp.2019.38.1.70

Lozano, A. B., do Nascimento Mascarenhas, S. A., Brenlla-Blanco, J. C., \& Fraga, H. M. (2012). [Learning contexts, family determiners and school performance in students of secondary education in Galicia (Spain)]. AMAzônica, 8(1), 370-412.

Lynskey, M. T., Coffey, C., Degenhardt, L., Carlin, J. B., \& Patton, G. (2003). A longitudinal study of the effects of adolescent cannabis use on high school completion. Addiction, 98(5), 685-692. https://doi.org/10.1046/j.1360-0443.2003.00356.x

Macleod, J., Oakes, R., Copello, A., Crome, I., Egger, M., Hickman, M., Oppenkowski, T., Stokes-Lampard, H., \& Smith, G. D. (2004). Psychological and social sequelae of cannabis and other illicit drug use by young people: a systematic review of longitudinal, general population studies. The Lancet, 363(9421), 1579-1588. https://doi.org/10.1016/S01406736(04)16200-4

Martín, M., \& Megret, M. (2013). Funciones básicas de la familia. Pensamientos para el asesoramiento educativo [Basic functions of the family. Thoughts for educational counseling]. EduSol, 13(44), 60-71.

Maturana, A. (2011). Consumo de alcohol y drogas en adolescentes [Alcohol and drug consumption in adolescents]. Revista Médica Clínica Las Condes, 22(1), 98-109. 
Medina, N., \& Ferriani, M. (2010). Protective factors for preventing the use of drugs in the families of a Colombian locality. Revista Latino-Americana de Enfermagem, 18(Spec), 504-551. https://doi.org/10.1590/S0104-11692010000700004

Meier, M. H., Hill, M. L., Small, P. J., \& Luthar, S. S. (2015). Associations of adolescent cannabis use with academic performance and mental health: a longitudinal study of uppermiddle-class youth. Drug and Alcohol Dependence, 156, 207-212. https://doi.org/10.1016/j.drugalcdep.2015.09.010

Mejía, C. F., Gutiérrez, S., \& Perea, E. (2011). Asociación entre depresión y bajo rendimiento académico en estudiantes universitarios [Association between depression and poor academic achievement in university students]. Psicogente, 14(25), 67-75.

Melchior, M., Bolze, C., Fombonne, E., Surkan, P. J., Pryor, L., \& Jauffret-Roustide, M. (2017). Early cannabis initiation and educational attainment: is the association causal? Data from the French TEMPO study. International Journal of Epidemiology, 46(5), 1641-1650. https://doi.org/10.1093/ije/dyx065

Montañés, M., Bartolomé, R., Montañés, J., \& Parra, M. (2008). Influencia del contexto familiar en las conductas de los adolescentes [Influence of the family context on adolescent behaviors]. Ensayos, (17), 391-407.

Morales-Manrique, C. C., Bueno-Cañigral, F. J., Aleixandre-Benavent, R., \& ValderramaZurián, J. C. (2011). Creencias y motivos asociados al consumo de cannabis en académicos de la ciudad de Valencia, España [Beliefs and motives associated with cannabis use in scholars of Valencia city, Spain]. Trastornos Adictivos, 13(4), 151-159. https://doi.org/10.1016/S1575-0973(11)70031-9

Moreno, J., \& Chauta, L. (2012). Funcionalidad familiar, conducta externalizada y rendimiento académico en un grupo de adolescentes de la ciudad de Bogotá [Family functionality, externalized behavior, and academic achievement in a group of adolescents Bogotá city]. Psychologia, 6(1), 155-166. https://doi.org/10.21500/19002386.1177

Moyeda, I., Velasco, A. S., \& Ojeda, F. R. (2013). Autoeficacia en adolescentes en edad escolar: su relación con la depresión, el rendimiento académico y las relaciones familiares [Selfefficacy in school-age adolescents: its relationship with depression, academic achievement, and family relationships]. Anales de Psicología, 29(2), 491-500.

https://doi.org/10.6018/analesps.29.2.124691

National Institute on Drug Abuse (2020). Marijuana Research Report. How does marijuana use affect school, work, and social life? https://www.drugabuse.gov/publications/researchreports/marijuana/how-does-marijuana-use-affect-school-work-social-life

Navalon-Mira, A., \& Ruiz-Callado, R. (2017). Consumo de sustancias asociado con el rendimiento académico. Una investigación sobre estudiantes de educación secundaria [Substance use associated with academic performance. A research about secondary education students]. Health and Addictions, 17(1), 45-52.

Ormrod, J. E., Sanz, A. J. E., Soria, M. O., \& Carnicero, J. A. C. (2005). Aprendizaje humano [Human learning]. Madrid: Pearson Educación.

Ortega, F. R. F., Mendoza, J. V., \& Ballestas, L. F. F. (2014). Factores psicológicos en adolescentes escolares de bajo rendimiento académico: depresión y autoestima [Psychological factors in low performing school adolescents with academic: depression and self-esteem]. Encuentros, 12(2), 35-47.

Parreño, J. C., Castillo, O. G., Aguilar, J., Saldaña, A. G., Cacharrón, Y. B., \& Garrido, I. V. (2011). Un estudio cualitativo sobre el uso indebido de drogas en adolescentes [A 
qualitative study on drug abuse in adolescents]. Atención Primaria,43(8), 435-439. https://doi.org/10.1016/j.aprim.2010.08.003

Pérez-Milena, A., Martínez-Fernández, M. L., Redondo-Olmedilla, M., Nieto, C. Á., Pulido, I. J., \& Gallardo, I. M. (2012). Motivaciones para el consumo de tabaco en adolescentes de una escuela secundaria urbana [Motivations for tobacco consumption among adolescents in an urban high school]. Gaceta Sanitaria, 26(1), 51-57. https://doi.org/10.1016/j.gaceta.2011.03.021

Portellano, J. A. (2000). Introducción a la neuropsicología [Introduction to neuropsychology]. Madrid: McGraw-Hill.

Quejía M., Rodríguez M., Tinoco M., \& Moreno, P. (2007). Adolescencia, grupo de pares y uso de sustancias. Un estudio descriptivo y relacional [Adolescence, peer group and substance use. A descriptive and relational study]. Apuntes de Psicología, 25(3), 305-324.

Reynolds, G. S. (1973). Una cartilla de condicionamiento operante [A primer of operant conditioning]. San Diego: Editorial Ciencia de la Conducta. Universidad de California.

Robbins, T. W., Ersche, K. D., \& Everitt, B. J. (2008). Drug addiction and the memory systems of the brain. Annals of the New York Academy of Sciences, 1141(1), 1-21. https://doi.org/10.1196/annals.1441.020

Rodríguez, M., \& Mendivelso, F. (2018). Diseño de investigaciones transversales [Design of cross-sectional research]. Revista Médica Sanitas, 21, 141-146.

Rubino, T., Realini, N., Braida, D., Guidi, S., Capurro, V., Viganò, D., Guidali, C., Sala, M., Bartesaghi, R., \& Parolaro, D. (2009). Changes in hippocampal morphology and neuroplasticity induced by adolescent THC treatment are associated with cognitive $\begin{array}{lll}\text { impairment in 763-772. } & \text { adulthood. Hippocampus, 19(8), }\end{array}$ https://doi.org/10.1002/hipo.20554

Santander, S., Zubarew, T., Santelices, L., Argollo, P., Cerda, J., \& Bórquez, M. (2008). Influencia familiar como factor protector frente a conductas de riesgo en adolescentes chilenos [Family influence as a protective factor against risk behaviors in Chilean adolescents]. Revista Médica de Chile, 136(3), 317-324. https://doi.org/10.4067/S003498872012000200006

Schweinsburg, A. D., Brown, S. A., \& Tapert, S. F. (2008). The influence of marijuana use on neurocognitive functioning in adolescents. Current Drug Abuse Reviews, 1(1), 99-111. https://doi.org/10.2174/1874473710801010099

Smilkstein, G. (1978). The family APGAR: A proposal for a family function test and its uses by physicians. Journal of Family Practice, 6, 12-31.

Torres, Y., Muñoz, A.L., \& Ramírez, H. (1994). Vigilancia epidemiológica del abuso de sustancias psicoactivas "VESPA" Medellín, Antioquia 1992 [Epidemiological surveillance on the abuse of psychoactive substances "VESPA" Medellín, Antioquia 1992]. Boletín Epidemiológico de Antioquia, 19, 180-193.

United Nations Office on Drugs and Crime. (2018). World drug report. New York.

Velázquez, L., \& Soriano, N. (2006). Rendimiento académico y contexto familiar en estudiantes universitarios [Academic performance and the family context in college students]. Enseñanza e Investigación en Psicología, 11(2), 255-270.

Verweij, K. J., Huizink, A. C., Agrawal, A., Martin, N. G., \& Lynskey, M. T. (2013). Is the relationship between early-onset cannabis use and educational attainment causal or due to common liability? Drug and Alcohol Dependence, 133(2), 580-586. https://doi.org/10.1016/j.drugalcdep.2013.07.034 
Volkow, N. D., Swanson, J. M., Evins, A. E., DeLisi, L. E., Meier, M. H., Gonzalez, R., Bloomfield, M. A. P., Curran, H. V., \& Baler, R. (2016). Effects of cannabis use on human behavior, including cognition, motivation, and psychosis: a review. JAMA Psychiatry, 73(3), 292-297. https://doi.org/10.1001/jamapsychiatry.2015.3278

World Health Organization. (1992). ICD-10. The tenth revision of the international classification of diseases. Mental and behavioral disorders. Madrid: Méditor.

World Health Organization: Regional Office for Europe (1998). Well-Being measures in primary health care: The DepCare Project. Consensus meeting, Stockholm.

Zarrouq, B., Bendaou, B., El Asri, A., Achour, S., Rammouz, I., Aalouane, R., Lyoussi, B., Khelafa, S., Bout, A., Berhili, N., Hlal, H., Najdi, A., Nejjari, C., \& El Rhazi, K. (2016). Psychoactive substances use and associated factors among middle and high school students in the North Center of Morocco: a cross-sectional questionnaire survey. BMC Public Health, 16(1), 468. https://doi.org/10.1186/s12889-016-3143-5 